\title{
PENGARUH PENDEKATAN SAINTIFIK MELALUI MODEL DISCOVERY LEARNING DENGAN PERMAINAN TERHADAP HASIL BELAJAR MATEMATIKA SISWA KELAS 5 SD
}

\author{
Wahyudi \& Mia Christy Siswanti \\ Pendidikan Guru Sekolah Dasar - FKIP - UKSW - Salatiga
}

\begin{abstract}
ABSTRAK
Latar belakang dalam penelitian ini adalah kegiatan pembelajaran matematika yang masih menekankan pada konsep hafalan sehingga siswa hanya berpusat pada angka dan rumus. Pemerintah menyajikan solusi yang menarik melalui kurikulum 2013 yang tertulis dalam Permendikbud Nomor 57 Tahun 2014. Sebelum pendekatan beserta model pembelajaran dalam kurikulum 2013 dibuktikan keberhasilnya, pemerintah telah menetapkan berhentinya kurikulum 2013 (Permendikbud Nomor 160 Tahun 2014). Tujuan dari penelitian ini adalah untuk mengetahui pengaruh pendekatan saintifik melalui model discovery learning dengan permainan terhadap hasil belajar siswa kelas 5 semester II SD kristen 03 Eben Haezer Salatiga tahun pelajaran 2014/2015.Jenis penelitian ini adalah penelitian eksperimen semu dengan metode Quasi Eksperimen Research. Desain penelitian yang digunakan adalah Nonequivalent Control Group Design dan teknik pengambilan sampel sampling jenuh. Populasi penelitian ini adalah seluruh siswa kelas V paralel SD Kristen 03 Eben Haezer Salatiga. Teknik pengumpulan data menggunakan observasi, dan tes. Berdasarkan hasil penelitian diperoleh bahwa ada pengaruh penerapan pendekatan saintifik melalui model discovery learning dengan permainan terhadap hasil belajar matematika siswa kelas 5 semester II SD Kristen 03 Eben Haezer Salatiga Tahun Pelajaran 2014/2015. Rata-rata kelas eksperimen 80,84 sedangkan kelas kontrol 71,75. Hal ini juga didukung dari nilai t hitung $>\mathrm{t}$ tabel, yaitu $(4,905>2.018)$ dan signifikan $0,000<0,05$ yang menunjukkan bahwa $\mathrm{H}_{0}$ ditolak $\mathrm{H}_{1}$ diterima.
\end{abstract}

Kata kunci: saintifik, discovery learning, permainan,hasil belajar, matematika, sekolah dasar.

\section{PENDAHULUAN}

Salah satu jenjang pendidikan yang penting dan diwajibkan di Indonesia adalah Pendidikan Sekolah Dasar (SD). Pasal 31 ayat (2) UUD 1945 berbunyi: "Setiap warga negara wajib mengikuti pendidikan dasar dan pemerintah wajib membiayainya". Untuk itu, pendidikan dasar inilah yang selanjutnya dikembangkan untuk meningkatkan kualitas diri anak didik. Peningkatan kualitas diri anak didik tertulis di dalam kurikulum. 
Kurikulum menjadi pedoman dalam penyelenggaraan proses pembelajaran untuk mencapai tujuan pendidikan. Pengertian Kurikulum Menurut UU No. 20 Tahun 2003: Kurikulum adalah seperangkat rencana dan pengaturan mengenai tujuan, isi, dan bahan pelajaran serta cara yang digunakan sebagai pedoman penyelenggaraan kegiatan pembelajaran untuk mencapai tujuan pendidikan nasional. Kurikulum berkembang dinamis sesuai dengan perkembangan jaman, tuntutan masyarakat, tantangan yang ada di masyarakat, dan kebutuhan masyarakat. Kurikulum terbaru yang diterbitkan pemerintah adalah kurikulum 2013 yang dirancang salah satunya dengan menekankan pada pendekatan saintifik.

Pendekatan saintifik menurut Daryanto (2014: 51) adalah proses pembelajaran yang dirancang sedemikian rupa agar peserta didik secara aktif mengkontruksi konsep, hukum atau prinsip melalui tahapan-tahapan mengamati (untuk mengdentifikasi atau menemukan masalah), merumuskan masalah, mengajukan atau merumuskan hipotesis, mengumpulkan data dengan berbagai teknik, menganalisis data, menarik kesimpulan dan mengkomunikasikan konsep, hukum atau prinsip yang ditemukan.

Untuk memperkuat pendekatan ilmiah (scientific), tematik terpadu (tematik antarmata pelajaran), dan tematik (dalam suatu mata pelajaran) perlu diterapkan pembelajaran berbasis penyingkapan/penelitian(discovery/inquiry learning) Permendikbud Nomor 65 (2013:2). Ridwan Abdullah (2014: 88) mengatakan bahwa kegiatan belajar mengajar menggunakan metode penemuan (discovery) adalah menemukan konsep melalui serangkaian data atau informasi yang diperoleh melalui pengamatan atau percobaan. Ridwan Abdullah (2014: 88) mengatakan bahwa kegiatan belajar mengajar menggunakan metode penemuan (discovery) adalah menemukan konsep melalui serangkaian data atau informasi yang diperoleh melalui pengamatan atau percobaan. Kegiatan belajar seperti ini sesuai dengan teori Bruner yang menyarankan agar siswa belajar secara aktif untuk membangun konsep dan prinsip.

Pembelajaran yang berbasis pada penemuan seperti Discovery Learning merupakan salah satu model pembelajaran yang dapat mengajarkan kemampuan berpikir logis, analitis, dan sistematis karena dengan siswa dapat menyelesaikan permasalahan, membangun dan menemukan suatu konsep dengan mandiri. Kemampuan berpikir logis, analitis, dan sistematis dapat diwujudkan di SD melalui pembelajaran yang PAKEM (Pembelajaran Aktif Kreatif Efektif dan Menyenangkan).

PAKEM dapat diwujudkan salah satunya dengan permainan. Menurut teori belajar Dienes, berhubungan dengan tahap belajar, suatu anak didik dihadapkan pada permainan yang terkontrol dengan berbagai sajian. Kegiatan ini menggunakan kesempatan untuk membantu anak didik menemukan cara-cara dan juga untuk mendiskusikan temuan-temuannya. Langkah ini merupakan salah 
satu cara untuk memberi kesempatan kepada siswa agar dapat berpartisipasi dalam proses penemuan. Permainan merupakan slah satu cara yang cocok digunakan dalam pembelajaran di SD karena sesuai dengan karakteristik anak SD yang suka bermain.

Pendekatan saintifik melalui model discovery learning dengan permainan merupakan salah satu cara untuk dapat meningkatkan kemampuan berpikir logis, analitis, dan sistematis siswa dalam mata pelajaran matematika. Setelah siswa mampu berpikir logis, analitis, dan sistematis di dapatkan diharapkan dengan treatmen yang dilakukan dapat meningkatkan hasil belajar siswa SD. Hasil belajar merupakan suatu keberhasilan siswa yang diperoleh dari hasil belajarnya. Oleh karenaitu, hasil belajar merupakan suatu ukuran berhasil tidaknya peserta didik setelah menempuh pelajaran. Hasil belajar tersebut sangat penting bagi peserta didik karena sebagai tolok ukur langsung yang sering dipakai oleh guru untuk mengetahui pemahaman siswa mengenai materi yang telah diberikan.

Materi pelajaran yang sering menjadi momok bagi peserta didik adalah Matematika. Matematika sering menjadi mata pelajaran yang ditakuti peserta didik karena berkaitan dengan angka-angka, rumus-rumus yang jauh dari dunia siswa dan mengkondisikan siswa untuk menghafal. Seharusnya pembelajaran matematika dilakukan dengan menggunakan benda-benda yang konkrit sehingga siswa lebih mudah memahami. Selain itu melalui sebuah kegiatan investigasi dan menemukan siswa mampu berpikir lebih logis, analitis dan sistematis sehingga pembelajaran menjadikan siswa lebih aktif dan memberikan pengalaman yang tidak mudah begitu saja untuk dilupakan.

Proses kerja ilmiah merupakan pendekatan yang diutamakan dalam kurikulum 2013. Model pembelajaran ini diterapkan dengan mengintegrasikan elemen-elemen pendekatan saintifik dalam pembelajaran. Sebelum pendekatan beserta metode pembelajaran tersebut dibuktikan keberhasilannya, pemerintah telah menetapkan berhentinya kurikulum 2013 dan digantikan dengan KTSP. Keputusan tersebut tertulis dalam Permendikbud Nomor 160 Tahun 2014 tentang Pemberlakukan Kurikulum Tahun 2006 dan Kurikulum 2013. Oleh karena itu, penelitian ini dilakukan untuk melihat perbedaan pengaruh yang signifikan antara pendekatan saintifik melalui model pembelajaran Discovery Learningberbantuan permainan dalam meningkatkan hasil belajar Matematika.

\section{KAJIAN TEORI}

\section{Matematika dan Pembelajaran di SD}

Johnson dan Rising dalam Russefendi (1972) dalam Erna Suwaningsih (2006: 4) matematika adalah pola berpikir, pola mengorganisasikan, pembuktian yang logis, matematika itu adalah bahasa yang menggunakan istilah yang 
didefinisikan dengan cermat, jelas, dan akurat representasinya dengan simbol dan padat, lebih berupa bahasa simbol mengenai ide daripada mengenai bunyi. Matematika adalah pengetahuan struktur yang terorganisasi, sifat-sifat dalam teoriteori dibuat secara deduktif berdasarkan kepada unsur yang tidak didefinisikan, aksioma, sifat atau teori yang telah dibuktikan kebenarannya adalah ilmu tentang keteraturan pola atau ide, dan matematika itu adalah suatu seni, keindahannya terdapat pada keterurutan dan keharmonisannya.

Dari berbagai pendapat mengenai Matematika, dapat disimpulkan bahwa Matematika adalah ilmu yang mempelajari tentang bilangan, bentuk-bentuk (geometri) yang dapat diekspresikan dan dioperasikan melalui simbol-simbolnya dimana memerlukan kacakapan berpikir khususnya dalam berlogika atau mengamati pola dan berpikir rasional.

Matematika di sekolah mendorong siswa berpikir secara logis, menganalis data, mengambil keputusan, dan memecahkan masalah yang timbul dalam situasi dan kehidupan nyata serta menggunakan konsep-konsep matematika dengan cara yang penuh makna, Muschla dan Muschla (2009: 3). Senada dengan pendapat Muschla. dan Muschla, Daryanto (2013: 411) juga mengungkapkan bahwa pembelajaran matematika perlu diberikan sejak sekolah dasar agar siswa mampu berpikir logis, analitis, sistematis, kritis, kreatif serta kemampuan bekerja sama. Menanamkan daya nalar dan membiasakan anak berfikir logis adalah tujuan pokok dari pembelajaran matematika di sekolah.

Pemahaman terhadap peranan pengajaran matematika di Sekolah Dasar sangat membantu para guru untuk memberikan pembelajaran matematika secara proporsional sesuai dengan tujuannya. Sebagaimana tercantum dalam dokumen BSNP (Badan Standar Nasional Pendidikan, 2006: 2) mata pelajaran matematika perlu diberikan kepada semua peserta didik mulai dari sekolah dasar untuk membekali peserta didik dengan kemampuan berpikir logis, analitis, sistematis, kritis, dan kreatif, serta kemampuan bekerjasama. Kompetensi tersebut diperlukan agar peserta didik dapat memiliki kemampuan memperoleh, mengelola, dan memanfaatkan informasi untuk bertahan hidup pada keadaan yang selalu berubah, tidak pasti, dan kompetitif.

\section{Pendekatan Saintifik}

Pendekatan saintifik adalah proses pembelajaran yang dirancang sedemikian rupa agar peserta didik secara aktif mengonstruk konsep, hukum atau prinsip melalui tahapan-tahapan mengamati (untuk mengidentifikasi atau menemukan masalah), merumuskan masalah, mengajukan atau merumuskan hipotesis, mengumpulkan data dengan berbagai teknik, menganalisis data, menarik kesimpulan dan mengomunikasikan konsep, hukum atau prinsip yang "ditemukan". 
Langkah-langkah pendekatan saintifik dalam pembelajaran disajikan sebagai berikut:

a. Mengamati

Metode mengamati mengutamakan kebermaknaan proses pembelajaran (meaningfull learning). Metode ini memiliki keunggulan tertentu, seperti menyajikan media obyek secara nyata, peserta didik senang dan tertantang, dan mudah pelaksanaannya. Metode mengamati sangat bermanfaat bagi pemenuhan rasa ingin tahu peserta didik.

b. Menanya

Guru perlu membimbing peserta didik untuk dapat mengajukan pertanyaan: pertanyaan tentang yang hasil pengamatan objek yang konkrit sampai kepada yang abstra berkenaan dengan fakta, konsep, prosedur, atau pun hal lain yang lebih abstrak.

c. Mengumpulkan Informasi

Kegiatan ini dilakukan dengan menggali dan mengumpulkan informasi dari berbagai sumber melalui berbagai cara.

d. Mengasosiasi/Mengolah informasi/Menalar

Memproses informasi yang sudah dikumpulkan baik terbatas dari hasil kegiatan mengumpulkan/eksperimen maupun hasil dari kegiatan mengamati dan kegiatan mengumpulkan informasi.

e. Menarik kesimpulan

Setelah menemukan keterkaitan antar informasi dan menemukan berbagai pola dari keterkaitan tersebut, selanjutnya secara bersama-sama dalam satu kesatuan kelompok, atau secara individual membuat kesimpulan.

f. Mengkomunikasikan

Kegiatan ini dapat dilakukan melalui menuliskan atau menceritakan apa yang ditemukan dalam kegiatan mencari informasi, mengasosiasikan dan menemukan pola.

\section{Discovery Learning}

Metode Discovery Learning adalah teori belajar yang didefinisikan sebagai proses pembelajaran yang terjadi bila pelajar tidak disajikan dengan pelajaran dalam bentuk finalnya, tetapi diharapkan siswa mengorganisasi sendiri. Pada Discovery Learning lebih menekankan pada ditemukannya konsep atau prinsip yang sebelumnya tidak diketahui.

Imam Kurinasih (2014: 64), menuliskan langkah-langkah (sintak) operasional Discovery Learningsebagai berikut: 
Tabel 1

Sintak Discovery Learning

\begin{tabular}{|r|l|}
\hline \multicolumn{1}{|c|}{ No } & \multicolumn{1}{|c|}{ Sintak discovery learning } \\
\hline 1. & $\begin{array}{l}\text { Guru memaparkan topik yang akan dikaji, tujuan belajar, motivasi, dan } \\
\text { memberikan penjelasan ringkas. }\end{array}$ \\
\hline 2. & $\begin{array}{l}\text { Guru mengajukan permasalahan atau pertanyaan yang terkait dengan topik } \\
\text { yang dikaji. }\end{array}$ \\
\hline 3. & $\begin{array}{l}\text { Kelompok merumuskan hipotesis dan merancang percobaan atau } \\
\text { mempelajari tahapan percobaan yang dipaparkan oleh guru, LKS, atau } \\
\text { buku. Guru memimbing dalam perumusan hipotesis dan merencanakan } \\
\text { percobaan. }\end{array}$ \\
\hline 4. & Guru memfasilitasi kelompok dalam melaksanakan percobaan /investigasi \\
\hline 5. & $\begin{array}{l}\text { Kelompok melakukan percobaan atau pengamatan untuk mengumpulkan } \\
\text { data yang dibutuhkan untuk menguji hipotesis. }\end{array}$ \\
\hline 6. & $\begin{array}{l}\text { Kelompok mengorganisasi dan menganalisis data serta membuat laporan } \\
\text { hasil percobaan atau pengamatan. }\end{array}$ \\
\hline 7. & $\begin{array}{l}\text { Kelompok memaparkan hasil investgasi (percobaan atau pengamatan) dan } \\
\text { mengemukakan konsep yang ditemukan. Guru membimbing peserta didik } \\
\text { dalam mengkonstruksi konsep berdasarkan hasil investigasi. }\end{array}$ \\
\hline
\end{tabular}

\section{Permainan}

Menurut Kimpraswil (dalam As'adi Muhammad, 2009: 26) mengatakan bahwa definisi permainan adalah usaha olah diri (olah pikiran dan olah fisik) yang sangat bermanfaat bagi peningkatan danpengembangan motivasi,kinerja, dan prestasi dalam melaksanakan tugas dan kepentingan organisasi dengan lebih baik. Menurut beberapa pendapat para ahli tersebut peneliti menyimpulkan definisi permainan adalahsuatu aktifitas yang dilakukan oleh beberapa anak untuk mencari kesenangan yang dapatmembentuk proses kepribadian anak dan membantu anak mencapai perkembangan fisik, intelektual, sosial, moral dan emosional.

Dalam Sri Subarinah (2006:5), Dienes berpendapat bahwa konsep-konsep matematika akan mudah dan berhasil untuk dipelajari apabila melalui tahapantertentu yang dibedakan dalam enam tahapan berurutan sebagai berikut:

a. Tahap Permainan Bebas (Free Play). Pada tahap ini siswa belajar matematika melalui permainan benda kongkret tanpa arahan guru, yang penting benda-benda yang dipakai untuk bermain sudah tersedia.

b. Tahap Permainan (Games). Pada tahap ini anak-anak juga masih bermain benda kongkret tetapi sudah diarahkan untuk mengamati pola dan keteraturan suatu konsep. 
c. Tahap Penelaahan Kesamaan Sifat (Searching for Communities). Pada tahap ini anak-anak melakukan kegaiatn belajar untuk menemukan kesamaan sifat melalui perminan yang dirancang guru.

d. Tahap Simbolis (Symbolism). Pada tahap ini siswa mulai menciptakan simbol matematika atau rumusan verbal. Misalnya untuk menuliskan segitiga ABC disimbolkan $\triangle \mathrm{ABC}$.

e. Tahap Simbolis (Symbolism). Pada tahap ini siswa mulai menciptakan simbol matematika atau rumusan verbal. Misalnya untuk menuliskan segitiga ABC disimbolkan $\triangle \mathrm{ABC}$.

f. Tahap Fomalisasi (Formalism). Pada tahap terakhir ini, siswa belajar mengorganisasi konsep-konsep membentuk suatu sistem matematika yang memuat aksioma, dalil, teorema beserta akibat-akibatnya. Tahap ini diluar jangkauan siswa SD.

\section{Hasil Belajar}

Arikunto dan Gagne dalam Sukiman (2012) mengungkapkan pada dasarnya hasil belajar adalah akibat dari adanya evaluasi belajar (tes) dan evaluasi belajar dilakukan untuk mengetahui kemampuan yang telah diperoleh siswa setelah melakukan proses pembelajaran. Tes tersebut dapat digunakan untuk mengukur secara jelas hasil belajar yang telah ditetapkan sesuai tujuan pembelajaran (Purwanto, 2010). Hasil belajar yang dimaksud dalam penelitian ini mengacu pada pendapat Arikunto dan Gagne, yaitu kemampuan yang dicapai oleh siswa setelah mengalami proses pembelajaran di kelas yang dapat dilakukan melalui evaluasi belajar (tes tertulis).

\section{METODE PENELITIAN}

Jenis penelitian ini menggunakan rancangan penelitian quasy exsperiment (eksperimen semu). Desain yang digunakan dalam penelitian ini, yaitu Nonequivalent Control Group Design, karena penelitian ini terdapat dua kelompok subjek yang tidak dipilih secara random (Sugiono, 2010: 116). Sampel penelitian adalah siswa kelas 5B SD Kristen 03 Eben Haezer Salatiga sebagai kelas eksperimen yang diberikan perlakuan berupa pembelajaran pendekatan saintifik melalui model Discovery Learning, berjumlah 22 siswa. Sedangkan kelas 5A SD Kristen 03 Eben Haezer Salatiga sebagai kelas kontrol yang tidak diberikan perlakuan, berjumlah 22 siswa. Data dikumpulkan dengan menggunakan instrumen lembar observasi dan lembar soal (pretest dan posttest). Soal pretes digunakan untuk mengetahui kedua sampel dalam keadaan seimbang atau tidak (uji keseimbangan). Teknik analisis data sebelum perlakuan dilakukan sebagai uji 
prasyarat analisis untuk uji keseimbangan. Untuk keperluan uji keseimbangan, data hasil penelitian selanjutnya diolah menggunakan Uji t. Prasyarat untuk melakukan Uji t yaitu data harus normal dan homogen. Normal artinya sampel dalam keadaan yang seimbang, dan homogen artinya sampel memiliki rerata yang sama. Soal posttest digunakan untuk mengetahui hasil belajar matematika setelah dilakukan perlakuan. Uji normalitas penelitian ini menggunakan Shapiro-Wilk karena jumlah responden yang diteliti kurang dari 30 siswa. Uji homogenitas dan beda rata-rata menggunakan uji Independent Samples Test, dengan uji hipotesis menggunakan uji t dua pihak (Two Tail Test), (Sugiyono, 2014: 119-120). Analisis data yang dihitung dengan bantuan SPSS 20.0 for windows. Untuk menguji kelayakan instrumen menggunakan uji validitas, reliabititas, dan tingkat kesukaran soal.

\section{HASIL PENELITIAN DAN PEMBAHASAN}

Berdasarkan hasil observasi, gambaran pelaksaan penelitian pada kelas ekperimen (Pendekatan Saintifik melalui Model Discovery Learning dengan Permainan) dan kelas kontrol (Pendekatan Saintifik melalui Model Inkuiri) dapat terlaksana dengan baik.

Deskripsi data yang disajikan adalah data hasil pretest matematika semester II tahun pelajaran 2014/2015 sebelum perlakuan sebagai data kemampuan awal. Kemudian setelah diberikan perlakuan diperoleh data akhir melalui postestmatematika. Sebelum melakukan analisis data terlebih dahulu menyusun tabel distribusi frekuensi untuk menyederhanakan hasil nilai pretest dan posttest.Berikut ini adalah hasil tabel distribusi frekuensi pretest dan posstest:

\section{Tabel 2}

Hasil Pretest Kelas Eksperimen

\begin{tabular}{|c|c|c|}
\hline \multirow{2}{*}{ Interval } & \multicolumn{2}{|c|}{ Kelas Eksperimen } \\
\cline { 2 - 3 } & Frekuensi & Persentase \\
\hline $67-71$ & 2 & $9,09 \%$ \\
\hline $72-76$ & 8 & $36,36 \%$ \\
\hline $77-81$ & 4 & $18,18 \%$ \\
\hline $82-86$ & 4 & $18,18 \%$ \\
\hline $87-91$ & 2 & $9,09 \%$ \\
\hline $92-96$ & 2 & $9,09 \%$ \\
\hline $\mathrm{N}$ & 22 & $100 \%$ \\
\hline
\end{tabular}


Tabel 3

\section{Hasil Pretest Kelas Kontrol}

\begin{tabular}{|c|c|c|}
\hline \multirow{2}{*}{ Interval } & \multicolumn{2}{|c|}{ Kelas Kontrol } \\
\cline { 2 - 3 } & Frekuensi & Persentase \\
\hline $67-72$ & 4 & $18,18 \%$ \\
\hline $73-78$ & 7 & $31,18 \%$ \\
\hline $79-83$ & 0 & $0,00 \%$ \\
\hline $84-88$ & 5 & $22,73 \%$ \\
\hline $89-94$ & 5 & $22,73 \%$ \\
\hline $95-100$ & 1 & $4,55 \%$ \\
\hline $\mathrm{N}$ & 22 & $100 \%$ \\
\hline
\end{tabular}

Tabel 4 dan tabel 5 memberikan gambaran tentang nilai siswa kelas eksperimen dan kelas kontrol yang diperoleh dari hasil posttest hasil belajar matematika. Sebelum diberi perlakuan, dilakukan uji prasyarat guna untuk mengetahui kedua kelas memiliki kemampuan awal yang sama. Uji prasyarat yang dimaksud yaitu uji normalitas dan uji homogenitas dilakukan melalui pretest.

Tabel 4

Hasil Posttest Kelas Eksperimen

\begin{tabular}{|c|c|c|}
\hline \multirow{2}{*}{ Interval } & \multicolumn{2}{|c|}{ Kelas Eksperimen } \\
\cline { 2 - 3 } & Frekuensi & Persentase \\
\hline $72-75$ & 5 & $22,73 \%$ \\
\hline $76-79$ & 7 & $31,82 \%$ \\
\hline $80-83$ & 4 & $18,18 \%$ \\
\hline $84-87$ & 2 & $9,09 \%$ \\
\hline $88-91$ & 2 & $9,09 \%$ \\
\hline $92-95$ & 2 & $9,09 \%$ \\
\hline $\mathrm{N}$ & 22 & $100 \%$ \\
\hline
\end{tabular}


Tabel 5

Hasil Postest Kelas Kontrol

\begin{tabular}{|c|c|c|}
\hline \multirow{2}{*}{ Interval } & \multicolumn{2}{|c|}{ Kelas Kontrol } \\
\cline { 2 - 3 } & Frekuensi & Persentase \\
\hline $61-64$ & 2 & $9,09 \%$ \\
\hline $65-68$ & 6 & $27,27 \%$ \\
\hline $69-72$ & 4 & $18,18 \%$ \\
\hline $73-76$ & 5 & $22,73 \%$ \\
\hline $77-80$ & 4 & $18,18 \%$ \\
\hline $81-84$ & 1 & $4,55 \%$ \\
\hline $\mathrm{N}$ & 22 & $100 \%$ \\
\hline
\end{tabular}

Uji normalitas ini dilakukan untuk mengetahui data empirik yang diperoleh berdistribusi normal atau tidak. Uji normalitas dilakukan menggunakan ShapiroWilk dengannilai signifikan $>0.05$ maka data tersebut normal, sedangkan nilai signifikan $<0.05$ maka data tidak berdistribusi normal. Uji homogenitas dilakukan untuk mengetahui apakah ada kesamaan varian antara kelas eksperimen dan kelas kontrol. Untuk uji homogenitas menggunakan Levene Statistic dengan nilai signifikan >0.05. Hasil uji normalitas dan uji homogenitaspretest dapat dilihat pada tabel berikut:

Tabel 6

\section{Hasil Uji Normalitas Pretest Kelas Eksperimen dan Kelas Kontrol}

\begin{tabular}{|c|c|c|c|c|c|c|c|}
\hline \multirow{4}{*}{$\mathrm{X}$} & \multirow[t]{2}{*}{ K } & \multicolumn{3}{|c|}{ Kolmogorov-Smirnov $^{\mathrm{a}}$} & \multicolumn{3}{|c|}{ Shapiro-Wilk } \\
\hline & & Statistic & Df & Sig. & Statistic & Df & Sig. \\
\hline & 1 & .184 & 22 & .050 & .928 & 22 & .109 \\
\hline & 2 & 217 & 22 & .008 & .940 & 22 & .196 \\
\hline
\end{tabular}

Tabel 6 menunjukkan hasil analisis uji normalitas hasil belajar matematika kelas ekperimen dan kelas kontrol. Dengan menggunakan Shapiro-Wilk (karena sampel < 30), jika nilai signifikan > 0,05, maka data berdistribusi normal. Jadi berdasarkan analisis hasil belajar matematika pada pretestkelas eksperimen memiliki nilai signifikansi $>0,05(0,109>0,05)$, dan kelas kontrol memiliki nilai signifikansi $>0,05(0,196>0,05)$, sehingga pada kelas eksperimendan kelas kontrol berdistribusi normal. 
Tabel 7

Hasil Uji Homogenitas Pretest Kelas Eksperimen dan Kelas Kontrol

\begin{tabular}{|l|l|r|r|r|r|}
\hline \multicolumn{2}{|c|}{} & \multicolumn{1}{c|}{$\begin{array}{c}\text { Levene } \\
\text { Statistic }\end{array}$} & \multicolumn{1}{c|}{ df1 } & df2 & \multicolumn{1}{c|}{ Sig. } \\
\hline \multirow{4}{*}{ X } & Based on Mean & 2.753 & 1 & 42 & .104 \\
\cline { 2 - 6 } & Based on Median & 1.968 & 1 & 42 & .168 \\
\cline { 2 - 6 } & $\begin{array}{l}\text { Based on Median and } \\
\text { with adjusted df }\end{array}$ & 1.968 & 1 & 38.394 & .169 \\
\cline { 2 - 6 } & Based on trimmed mean & 2.642 & 1 & 42 & .112 \\
\hline
\end{tabular}

Tabel 7 menunjukkan hasil uji homogenitas dengan metode Levene's Test. Nilai Levene ditunjukkan pada baris nilai Based on Mean, yaitu 2,753 dengan $p$ value (sig) sebesar 0,104 dimana >0,05 yang berarti terdapat kesamaan varian antara kelas eksperimen dan kelas kontrol sebelum diberi perlakuan atau yang berarti homogen.

Berdasarkan uji keseimbangan Levene's Test for Equality of Variances diperoleh data bahwa nilai t sebesar -0,396 dengan nilai signifikansi sebesar 0,694 yang berarti lebih besar dari $0,05 \quad(0,694>0,05)$. Berdasarkan pada nilai signifikansi/probabilitas yaitu jika signifikansi >0,05, maka $\mathrm{H}_{0}$ diterima dan jika signifikansi < 0,05, maka $\mathrm{H}_{0}$ ditolak. Karena nilai signifikansi 0,694>0,05 maka $\mathrm{H}_{\mathrm{o}}$ diterima, berarti kedua kelas yaitu kelas eksperimen dan kelas kontrol dalam keadaan seimbang. Jadi antara siswa yang akan dilaksanakan pembelajaran menggunakan pendekatan saintifik melalui model Discovery Learning dan pendekatan saintifik dengan model inkuiri sebelum perlakuan mempunyai hasil belajar awal yang sama. Uji prasyarat hipotesis setelah perlakuan meliputi uji normalitas dan homogenitas. Hasil uji normalitas, uji homogenitas, dan uji hipotesis setelah perlakuan sebagai berikut:

\section{Tabel 8}

\section{Hasil Analisis Uji Normalitas Posstest Kelas Eksperimen dan Kontrol}

\begin{tabular}{|l|l|r|r|r|r|r|r|}
\hline \multirow{3}{*}{ Pelas } & \multirow{3}{*}{ Kelas } & \multicolumn{3}{|c|}{ Kolmogorov-Smirnov } & \multicolumn{3}{|c|}{ Shapiro-Wilk } \\
\cline { 2 - 8 } & & Statistic & \multicolumn{1}{c|}{ Df } & \multicolumn{1}{c|}{ Sig. } & Statistic & \multicolumn{1}{c|}{ df } & \multicolumn{1}{c|}{ Sig. } \\
\cline { 2 - 8 } & 1 & .187 & 22 & .044 & .936 & 22 & .167 \\
\cline { 2 - 8 } & 2 & .159 & 22 & .151 & .949 & 22 & .296 \\
\hline
\end{tabular}

Berdasarkan Tabel 8 menunjukkan hasil analisis uji normalitas skor posttest hasil belajar matematika kelas eksperimen dan kelas kontrol. Jika nilai signifikansi pada Shapiro-Wilk lebih besar dari 5\% atau 0,05 maka data berdistribusi normal. 
Tabel 9

Hasil Uji HomogenitasPosttest Kelas Eksperimen dan Kontrol

\begin{tabular}{|l|l|r|r|r|r|}
\hline \multicolumn{2}{|c|}{} & $\begin{array}{c}\text { Levene } \\
\text { Statistic }\end{array}$ & df1 & df2 & \multicolumn{1}{c|}{ Sig. } \\
\hline \multirow{4}{*}{ Postes } & Based on Mean & .030 & 1 & 42 & .864 \\
\cline { 2 - 6 } & Based on Median & .000 & 1 & 42 & 1.000 \\
\cline { 2 - 6 } & $\begin{array}{l}\text { Based on Median and with } \\
\text { adjusted df }\end{array}$ & .000 & 1 & 39.311 & 1.000 \\
\cline { 2 - 6 } & Based on trimmed mean & .024 & 1 & 42 & .878 \\
\hline
\end{tabular}

Tabel 9 menunjukkan hasil uji homogenitas dengan metode Levene's Test. Nilai Levene ditunjukkan pada baris nilai Based on Mean, yaitu 0,030 dengan $p$ value (sig) sebesar 0,864 dimana 0,864>0,05 yang berarti terdapat kesamaan varians antara kelas eksperimen dan kelas kontrol setelah diberi perlakuan atau yang berarti homogen.

Selanjutnya dilakukan perhitungan uji hipotesis penelitian. Pengujian hipotesis merupakan langkah atau prosedur untuk menentukan apakah hipotesis diterima atau ditolak.

Uraian hipotesis penelitian diatas dapat ditulis dengan:

1. $\mathrm{H}_{0}: \mu_{1} \leq \mu_{2}$ artinya tidak ada pengaruh pembelajaran dengan menggunakan Pendekatan Saintifik melalui Model Discovery Learning dengan Permainanterhadap hasil belajar siswa kelas 5 semester II SD Kristen 03 Eben Haezer Salatiga tahun pelajaran 2014/2015.

2. $\mathrm{H}_{1}: \mu_{1}>\mu_{2}$ artinya ada pengaruh pembelajaran dengan menggunakan

Pendekatan Saintifik melalui Model Discovery Learning dengan Permainanterhadap hasil belajar siswa kelas 5 semester II SD Kristen 03 Eben Haezer Salatiga tahun pelajaran 2014/2015.

Untuk menguji hipotesis maka digunakan hasil output olahan SPSS 20.0 for windows.

Kriteria Pengujian:

(1) Menggunakan koefisien Sig., dengan ketentuan:

a. Jika nilai sig. Hitung (probabilitas) $<0,05$ maka tolak $\mathrm{H}_{0}$.

b. Jika nilai sig. Hitung (probabilitas) $>0,05$ maka terima $\mathrm{H}_{0}$

(2) Menggunakan koefisien t hitung, dengan ketentuan:

a. Jika koefisien $\mathrm{t}$ hitung $>\mathrm{t}$ tabel maka tolak $\mathrm{H}_{0}$.

b. Jika koefisien $\mathrm{t}$ hitung $<\mathrm{t}$ tabel maka terima $\mathrm{H}_{0}$.

Hasil perhitungan uji hipotesis menggunakan uji $t$ Independent Sample Test. Hasil perhitungan uji hipotesismenggunakan SPSS 20.0for windowsdengan taraf signifikan $\alpha=0,05$ disajikan pada tabel berikut: 
Tabel 10

Hasil Uji Hipotesis (Uji T Independent Samples Test Nilai Posttest) Kelas Eksperimen dan Kelas Kontrol

\begin{tabular}{|c|c|c|c|c|c|c|c|c|c|c|}
\hline & \multicolumn{2}{|c|}{$\begin{array}{c}\text { Levene's } \\
\text { Test }\end{array}$} & \multicolumn{7}{|c|}{ t-test for Equality of Means } \\
\hline & & \multirow[t]{2}{*}{$\mathrm{F}$} & \multirow[t]{2}{*}{ Sig. } & \multirow[t]{2}{*}{$\mathrm{t}$} & \multirow[t]{2}{*}{$\overline{\mathrm{Df}}$} & \multirow{2}{*}{$\begin{array}{c}\text { Sig. } \\
(2- \\
\text { tailed })\end{array}$} & \multirow[t]{2}{*}{$\begin{array}{l}\text { Mean } \\
\text { Diff. }\end{array}$} & \multirow[t]{2}{*}{$\begin{array}{l}\text { Std. Error } \\
\text { Diff. }\end{array}$} & \multicolumn{2}{|c|}{$\begin{array}{c}95 \% \\
\text { Confidence } \\
\end{array}$} \\
\hline & & & & & & & & & Lower & Upper \\
\hline \multirow[b]{2}{*}{ Post } & $\begin{array}{l}\text { Equal } \\
\text { variances } \\
\text { assumed }\end{array}$ & .030 & .864 & 4.905 & 42 & .000 & 9.090 & 1.853 & 5.350 & 12.830 \\
\hline & $\begin{array}{l}\text { Equal } \\
\text { variances } \\
\text { not } \\
\text { assumed }\end{array}$ & & & 4.905 & 41.938 & .000 & 9.090 & 1.853 & 5.350 & 12.831 \\
\hline
\end{tabular}

Berdasarkan tabel di atas dapat diketahui bahwa signifikansi dilihat dari Sig. (2-tailed) sebesar 0,000 , artinya $0,000<0,05$ nilai, $t_{\text {hitung }}$ sebesar 4,905 . Terdapat juga $\mathrm{df}=42$, sedangkan perbedaan rata-rata (mean diference) 9,090. Perbedaan mean differenceberkisar antara 5,350 sampai 12,830.

Penelitian ini juga dapat dilihat dari uji $\mathrm{t}$ dua pihak dengan $\mathrm{df}=42$ dan signifikansi $\alpha=5 \%$ maka diperoleh $\mathrm{t}$ tabel 2,018. Karena dari $\frac{1}{2} \alpha=\frac{1}{2} 5 \%=2,5 \%$. Jadi 2,5\% untuk kiri dan 2,5\% untuk kanan sehingga t tabel yang digunakan sebesar 2,018 diambil dari kolom two tail 0,000. Kriteria t hitung yang digunakan unutk pengambilan keputusan jika t hitung $>\mathrm{t}$ tabel maka $\mathrm{H}_{\mathrm{O}}$ ditolak. Dan jika $\mathrm{t}$ hitung $<\mathrm{t}$ tabel maka $\mathrm{H}_{\mathrm{O}}$ diterima. Untuk lebih ringkas, hasil perhitungan uji t dapat dilihat pada tabel dibawah ini.

\section{Tabel 11}

\section{Rangkuman Uji Hipotesis}

\begin{tabular}{|c|c|c|}
\hline $\mathbf{t}_{\text {hitung }}$ & $\mathbf{t}_{\text {tabel }}$ & Keputusan Uji \\
\hline 4,905 & 2,018 & $\mathrm{H}_{0}$ ditolak $_{1}$ diterima \\
\hline
\end{tabular}

Dari hasil uji t menunjukkan $\mathrm{t}$ hitung $>\mathrm{t}$ tabel, yaitu 4,905>2,018 dan signifikan $0,000<0,05$ yang menunjukkan bahwa $\mathrm{H}_{0}$ ditolakH $\mathrm{H}_{1}$ diterima. Hal ini menunjukkan bahwa ada pengaruh pembelajaran dengan menggunakanPendekatan Saintifik melalui Model Discovery Learning dengan Permainanterhadap hasil belajar matematika siswa kelas 5 semester II SD Kristen 03 Eben Haezer Salatiga tahun pelajaran 2014/2015. 
Pengaruh Pendekatan Saintifik melalui Model Discovery Learning dengan Permainan

Terhadap Hasil Belajar Matematika (Wahyudi \& Mia Christy Siswanti)

\section{SIMPULAN}

Berdasarkan hasil penelitian yang telah dilakukan dapat disimpulkan, bahwa terdapat pengaruh signifikan pembelajaran yang menggunakan pendekatan saintifik melalui model discovery learning dengan permainan terhadap hasil belajar matematika pada siswa kelas 5 SD semester II tahun pelajaran 2014/2015. Hal ini disebabkan karena pendekatan saintifik melalui model discovery learning dengan permainan dapat menjadikan pelajaran matematika yang identik dengan konsep angka, rumus, deduktif, aksiomatis dan cenderung hafalan menjadi pembelajaran yang lebih bermakna dam menyenangkan dengan adanya kegiatan ilmiah dengan siswa menemukan konsep melalui permainan. Selain itu dengan permainan dapat membantu siswa menemukan kosep dan mendiskusikan temuan-temuannya. Melalui kegiatan menemukan itu, mengajarkan siswa untuk berpikir logis, analitis, dan sistematis.

\section{DAFTAR PUSTAKA}

BNSP. 2007.Permendiknas Nomor 41 Tahun 2007 Tentang Standar Proses Untuk Satuan Pendidikan Dasar dan Menengah. Jakarta: Depdikbud.

BNSP. 2013. Permendikbud Nomor 65 Tahun 2013 Tentang Standar Proses Pendidikan Dasar dan Menengah. Jakarta. Depdikbud.

Dabel, John (diterjemahkan oleh Novita Heny Purwanti). 2009. Aktivitas Permainan dan Ide Praktis Belajar Matematika. Jakarta: Erlangga.

Hartono, Agung. 2002. Perkembangan Peserta Didik. Jakarta: PT Rineka Cipta.

Sani, Ridwan Abdullah. 2014. Pembelajaran Saintifik untuk Implementasi Kurikulum 2013. Jakarta: PT Bumi Aksara.

Santrock, John. 2014. Psikologi Pendidikan. Jakarta: Salemba Humanika.

Subarinah, Sri. 2006. Inovasi Pembelajaran Matematika SD. Jakata: Depdiknas.

Sugiyono. 2014. Metode Penelitian Pendidikan. Bandung: Alfabeta.

Suwangsih, Erna. 2006. Model Pembelajarn Matematika. Bandung: UPI Press Gedung Penerbitan dan Percetakan Universitas Pendidikan Indonesia.

Trihendradi, Cornelius. 2009. Step by Step SPSS 16 Analisis Data Statistik. Yogyakarta: C.V Andi Offset.

Wuryani, Sri. 2002. Psikologi Pendidikan. Jakarta: PT Gramedia Widiasarana Indonesia.

Widoyoko, Eko. 2012. Teknik Penyusunan Instrumen Penelitian. Yogyakarta: Pustaka Pelajar. 